Researches on Crustacea, No. 12 (1983)

Carcinological Society of Japan

Odawara Carcinological Museum

Azabu-Juban 3-11, Minatoku, Tokyo

(Issued-Aug. 30, 1983)

\title{
A FURTHER NOTE TO "FISHING GEAR FOR PRAWN AND SHRIMP USED IN THE PHILIPPINES TODAY"*
}

With 7 Text-figures

by

Hiroshi Мотон

(Central Laboratory, Marine Ecology Research Institute, 300, Iwawada, Onjuku, Isumi-gun, Chiba-ken, 299-51, Japan)

「フィリピンに和けるェビ漁具」追記

挿図 7

本 尾洋

(海洋生物環境研究所 中央研究所)

\section{Introduction}

Мотон (1980) reported 9 and 13 kinds of shrimping gear for the fry and the adult respectively, of which most of them are indigenously used today in the Philippines. However, during the continued ecological survey of penaeids in the country conducted by him and his staff, six kinds of shrimping gear or devices were additionally found by them, which have been used traditionally in the country.

The reasons that the present author intends to introduce the gear or devices are as follows: 1) To record these unique devices from the nature conservation point of view, which were invented by rural people through their long experiences, though devices been forgetten due to their poor catching effectiveness, and 2) To recommend the continuous use of these devices by local people, which impose much less construction technique and energy on the users compared to modern mechanized catching tools.

\section{Materials and methods}

The six kinds of gear for shrimp, prawn or lobster were found during the field trip 1980 to 1981 at the four different places: cover pot at Himamaylan, triangular scoop net, channel net and lobster cage at San Jose, motorized push net at Iloilo, and fyke net at

\footnotetext{
* Contribution No. 46 of the Aquaculture Department of the Southeast Asian Fisheries Development Center (SEAFDEC).
} 
Aparri. The localities of these four places are shown by Мотон $(1980,1981)$.

Illustractions given here (Figs. 1 to 7 ) were prepared by the scientific illustrator, Mr. Panfilio LEGASPI, Jr., based on the materials handled or color pictures and skectches taken and made by him and the present author.

\section{Observations and discussion}

1. Cover pot (Fig. 1)

The cover pot, locally called "Salakab", or "Taklob", is a portable conical shaped trap made of many pieces of split bamboos fastened with rattan (or sometimes synthetic material) forming a conical or sub-sylindrical shape in parallel series to circular frames as shown in Fig. 1. Although the size and mesh vary considerably by localities, the principal dimensions of the pot are as follows: Size of base in diameter, $34 \mathrm{~cm}$; size of upper opening in diameter, $16 \mathrm{~cm}$; the height, $52 \mathrm{~cm}$. The upper circular edge is thick with smooth surface to effect easy handling, while the lower end is tapering.

During low tide in the daytime in mangrove or estuarine areas, fisherman quickly sticks the pot by his one hand into favorite spot of the muddy place where he expects shrimps and/or others. Then he checks the muddy surface inside the pot whether catch was made or not by his another hand. The catch, when available, is taken out through

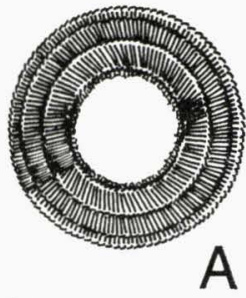

$10 \mathrm{~cm}$
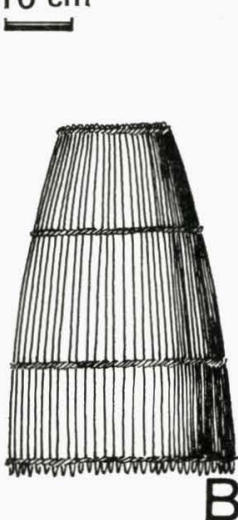
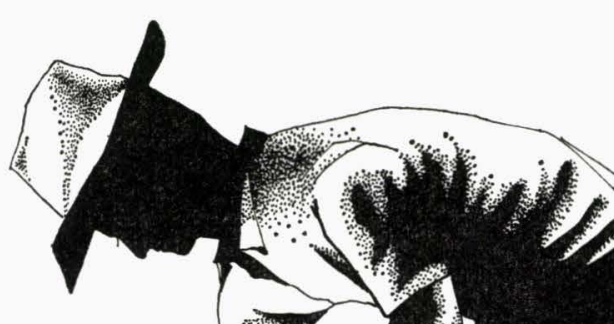

A

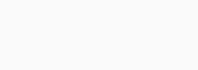


the upper opening by his hand, and sometimes he uses the device at night with an aid of a kerosene torch. At night shrimps and prawns seldom escape by the approaches of man, and fisherman claims that kerosene light helps his working, also plays a role to attract animals. According to pond workers, they also use the same pot to capture shrimps left over during their harvest of the crop.

The cover pot may belong to the same category of the cover net "Pingpong" as one of the set impounding net (МотоH, 1980). According to UMALI (1950), the name of "Taklob" is also used for another fishing gear, a small cast net operated in swiftflow or shallow river in the northern Mindanao for catching gobies ans sleepers.

\section{Triangular scoop net (Fig. 2)}

The triangular scoop net, known as "Sungya", is a simple scooping net with a handle operated by one person. It is consisiting of dredging and gathering parts. The former is made of finely wooven bamboo matting framed with a triangular and semiconical shape by half-cut bamboos which are rigidly tied at upper portion serving as a handle, and the latter Manila twine netting as a codend.

A fisherman operates this device at the stagnant portion of river where he expects the freshwater prawns, Macrobrachium and Palaemon spp., locally called "Ulang". To drive the animals, he proceeds on his foot slowly for scaring them and periodically lifts the net quickly to the water surface and to gather catches into the codend, further, to remove andy kinds of debris remained.

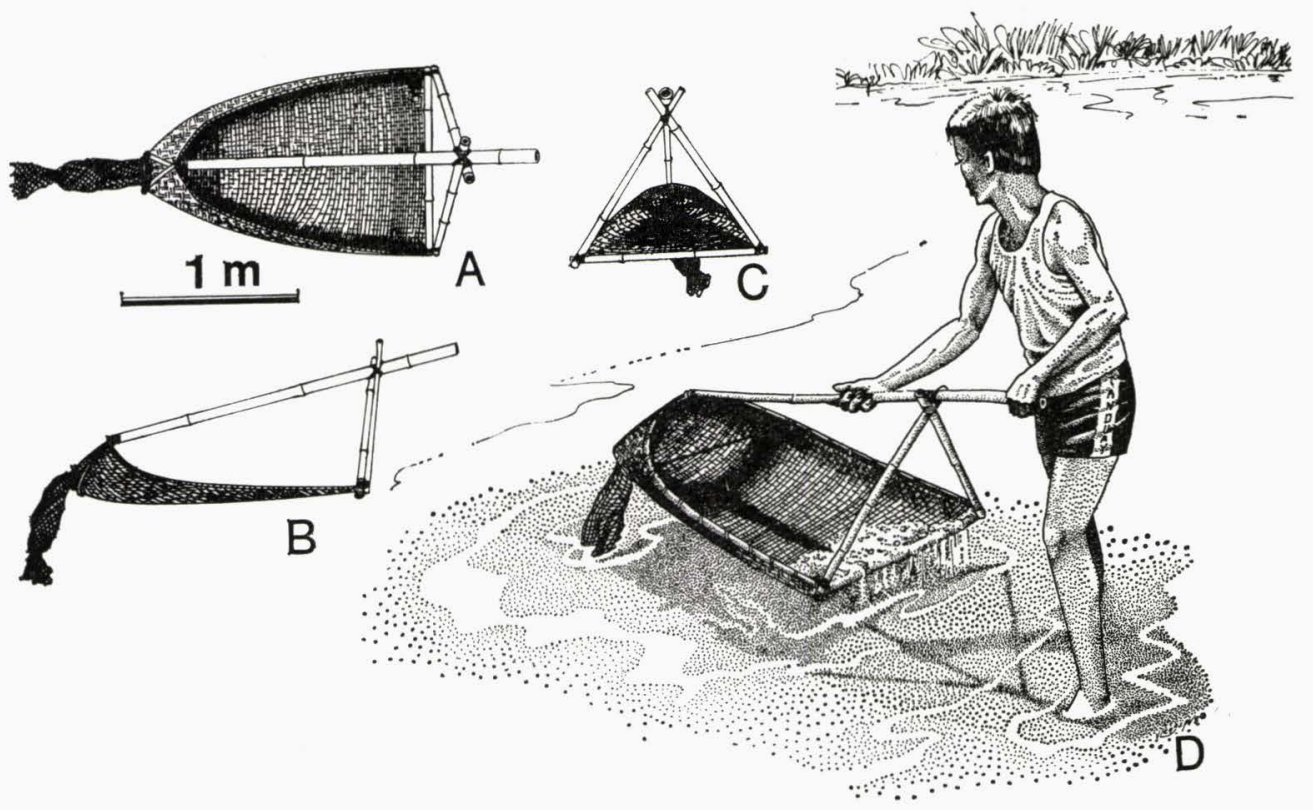

Fig. 2. Triangular scoop net. A, top view; B, side view; C, front view; D, operation. 
According to Talavera and Montalban (1932) and Umali (1950), the fisherman sometimes is accompanied by a "driver" who carries a scaring device to drive animals into the scoop net.

\section{Fyke net (Fig. 3)}

The fyke net, locally known as "Sayot", or "Sensoro", consists mainly of two wing nets and a pocket net (codend), both made of Manila twine. The principal dimensions of the net are as follows: length of wing net, $8 \mathrm{~m}$; depth of wing net, 0.8 to $2.4 \mathrm{~m}$; mesh size of wing net, $7 \mathrm{~mm}$; length of pocket net, $7 \mathrm{~m}$; mesh size of pocket net, $4 \mathrm{~mm}$.

The opening of the net is maintained with styrofoam floats and lead or stone sinkers lined in intervals of $30 \mathrm{~cm}$ and $32 \mathrm{~cm}$ respectively, furthermore a pair of bamboo or wooden pole of $1.3 \mathrm{~m}$ long being set at the front end of wing net.

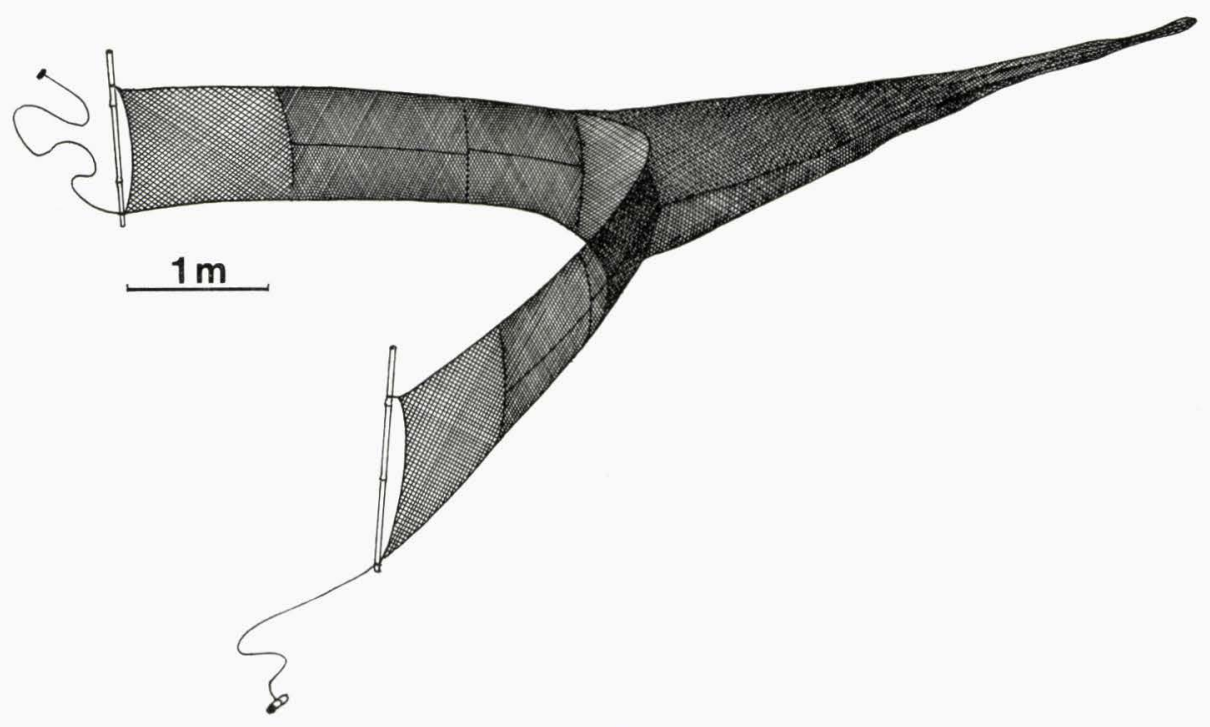

Fig. 3. Fyke net.

The net is slowly dragged in shallow water less than $1.3 \mathrm{~m}$, along sandy shore by 6 to 8 persons through the Manila cords and bamboo poles. After dragging for the distance of about $200 \mathrm{~m}$, the wing nets are shortened in order to drive the catch into the codend. The catch is removed through the posterior end of the pocket by untying the code.

The net catches usually white shrimps, Penaeus merguiensis, and $P$. indicus, locally called "Hipon puti", and the catch is abundant even during daytime when water is turbid.

In construction the fyke net is similar to the fry filter net (МотоH, 1980), though the latter is stationary in use as it receives the coming animals together with moderate current along the shore. 
4. Channel net (Fig. 4)

The channel net, locally called "Tangab", consists of a bag-shaped net, and the codend framed with bomboos. The dimensions are $3.9 \mathrm{~m}$ long, $3.7 \mathrm{~m}$ wide in bag-shaped net, and some $1.1 \times 1.3 \mathrm{~m}$ in codend. The codend is framed and floated with four pieces of bamboos in the shape of a rectangle as shown in the figure. The net is usually

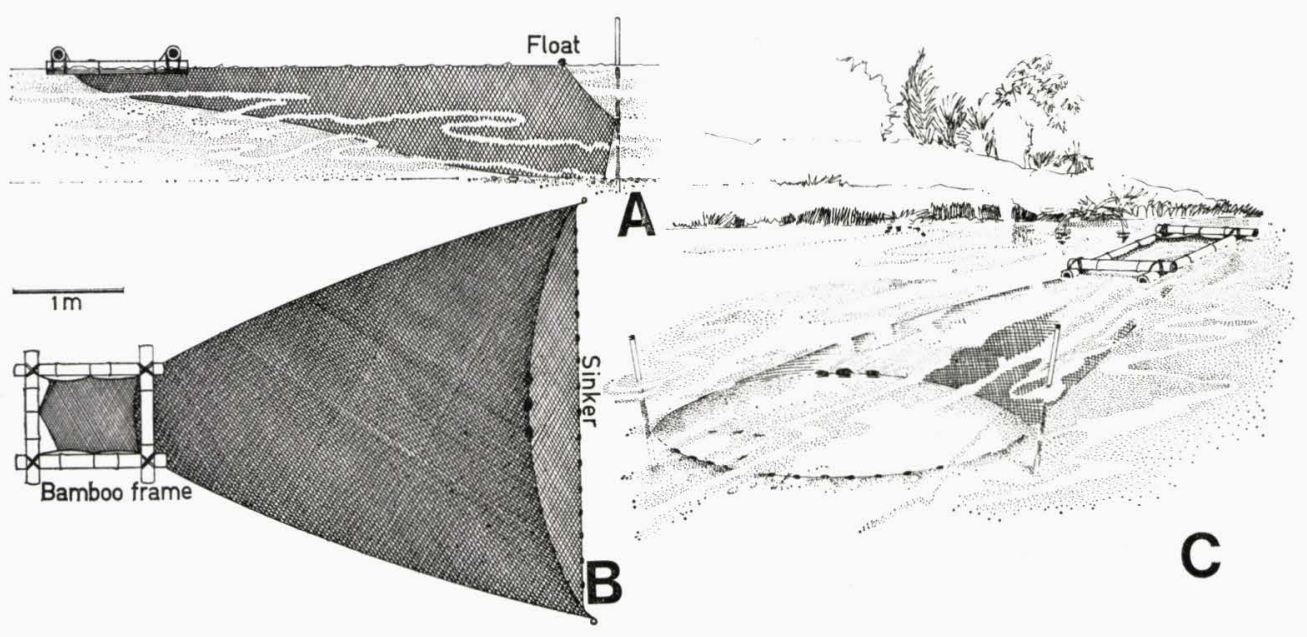

Fig. 4. Channel net. A, side and operational view; B. top view; C, operation.

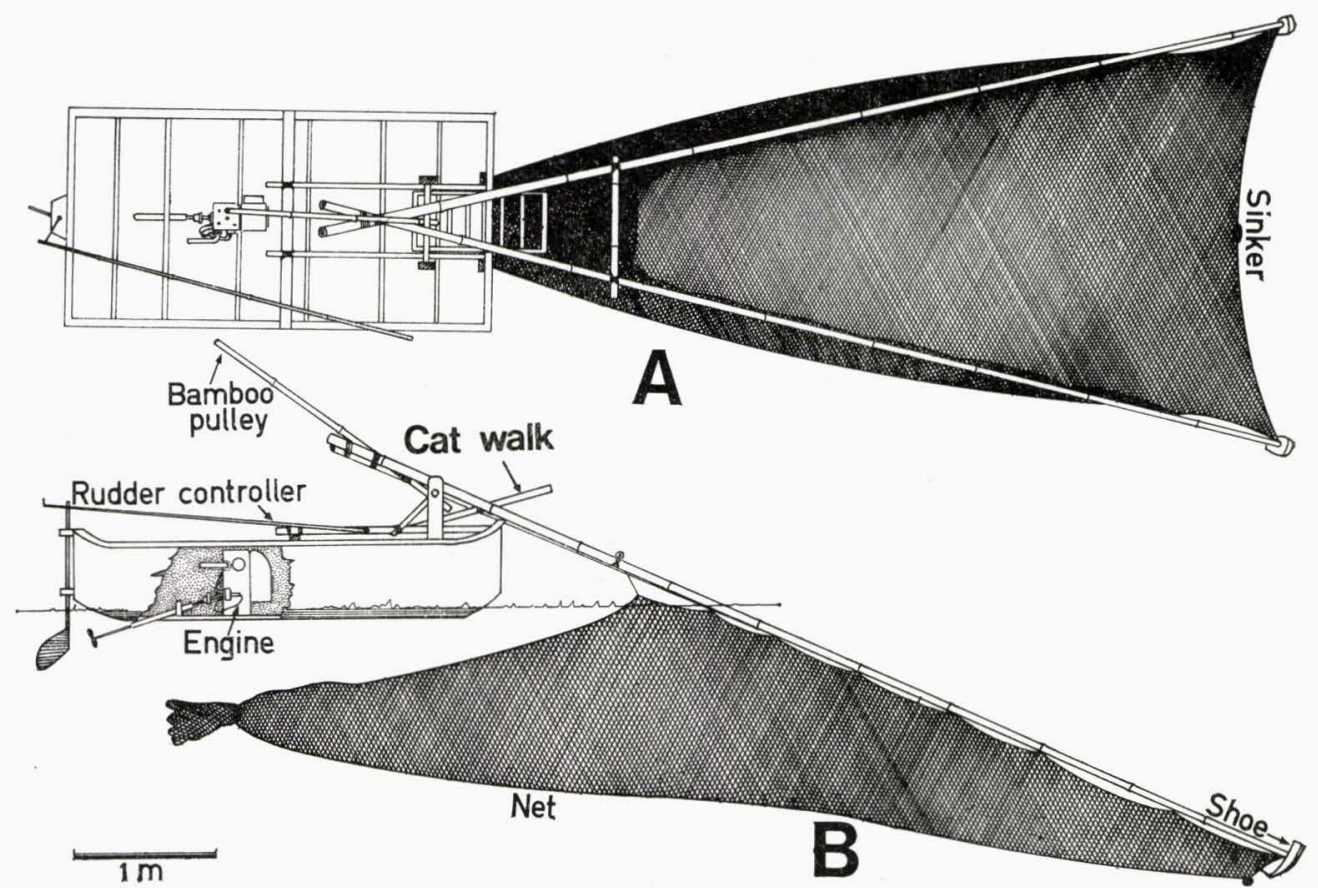

Fig. 5. Motorized push net. A, top view; B, side and semi-operational view. 
fastened to the two poles of mangrove tree in the water of fairly strong tidal currents from upstream, thus, filtering any shrimp and fish flowing. The net is lifted before the flowing water slackens as it is not furnished with the nonreturn valve. Frontal end of the net is lined with styrofoam floats and lead sinkers to keep the net open. The catch is periodically collected at the codend which is floating making easy harvest.

Basically the channel net has the similar construction and operation as the "Fry filter net" (Мотон, 1980), though the latter is operated in sandy shore but not mangrove area to collect fry of the giant tiger prawn, Penaeus monodon, and the fry of milkfish, Chanos chanos, popularly known as Sygpo" and "Bangos" respectively.

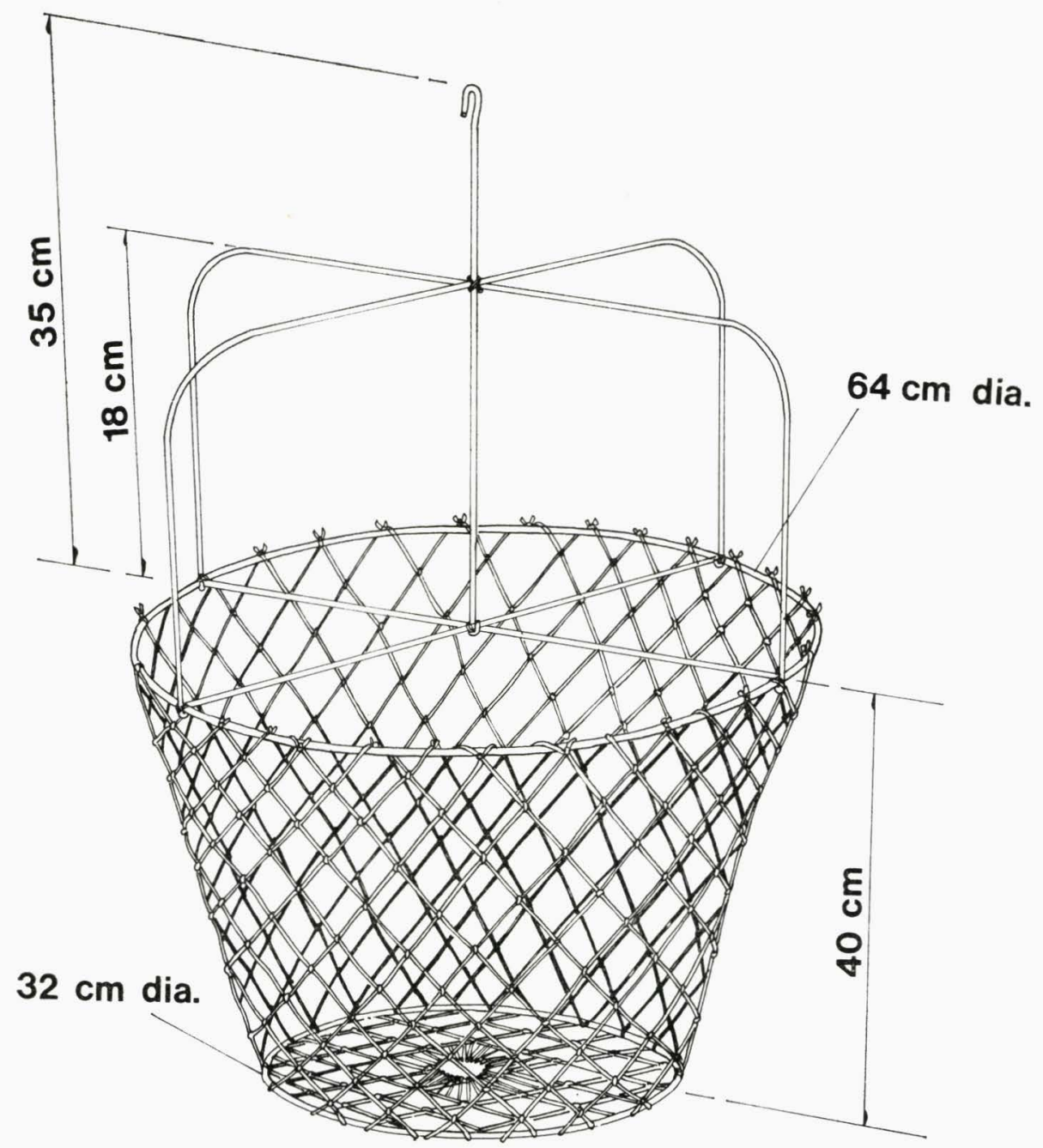

Fig. 6. Lobster cage 
5. Motorized push net (Fig. 5)

The push net, locally called "Huthut", consists of a triangular net $16 \mathrm{~m}$ long, two long bamboos $8 \mathrm{~m}$ long, and a pair of wooden shoes as shown in the figure. This gear, having the mesh size of the net about $9 \mathrm{~mm}$, is basically same as the skimming net described by Мотон (1980) in its construction and operation. The main differences are 1) it is operated or pushed by a flat-bottomed boat which is not equipped with outriggers, and 2) it is operated at fishing area where tidal current is weak. Thus the operation is mostly done when water is stagnant, since the boat lacks good turning movement.

The push net is usually operated by two persons at night, lasting about one hour per operation. On the harvest one person pulls the bamboo pulley down and the other staying on the catwalk collects the catch by a scoop net with a long bamboo handle. The posterior portion of the codend is untied when the catches are entirely taken out. The catch is usually middle-sized shrimp, Metapenaeus spp., locally called "Suaje" or "Hipon suaje", in addition to other animals such as crabs and fishes.

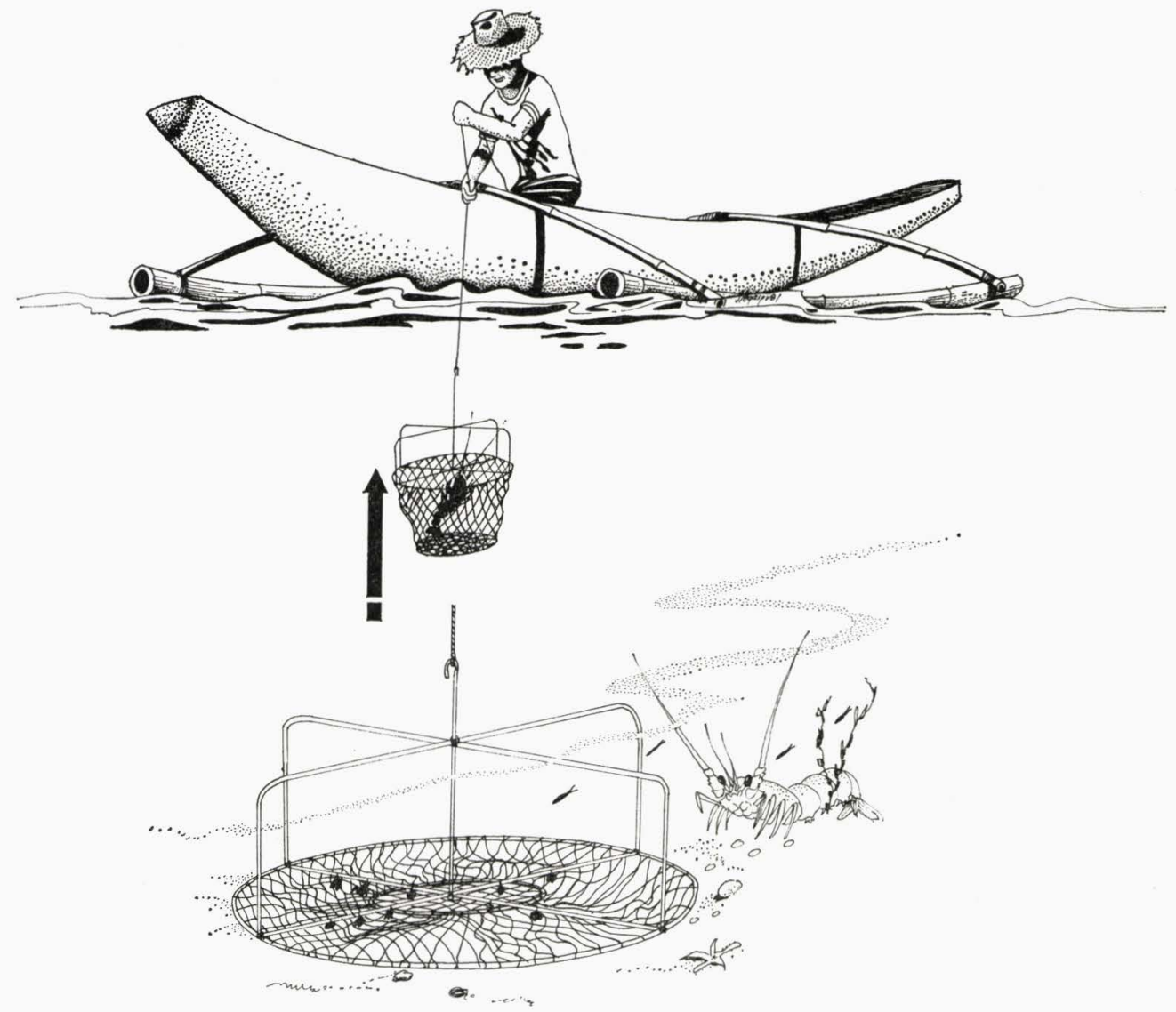

Fig. 7. Operation of the lobster cage (Fig. 6). 
6. Lobster cage (Figs. 6 and 7)

The lobster cage, locally called "Panak", is made of wire, netting and rope of Manila twine. As shown in the figures, it is a conical shaped cage with upper diameter $64 \mathrm{~cm}$ and the lower $32 \mathrm{~cm}$ and the height $40 \mathrm{~cm}$. It is not rigid but collapsible and is thrown from a dugout, known as "Banca", to the water down to about $50 \mathrm{~m}$ deep.

It is baited with a trash fish impaled on a wire placed on the middle of the trap, which is kept on the bottom where the lobsters inhabit. Then, the fisherman suddenly and quickly lifts the cage up so as to form a deep cage or pot to prevent the animal escaping, thus making the catching effort periodical (Fig. 7).

This cage aims to trap the lobster, Nephrops or Metanephrops sp. called "Banagan", and this type of gear for lobsters is used today only at San Jose area in the country as far as the present author is aware.

\section{Acknowledgement}

The author wishes to express his sincere gratitude to Dr. Katsuzo Kuronuma, President Emeritus, Tokyo University of Fisheries for his valuable advice through the study and review of the manuscript.

Thanks are also due to Mr. Prasit Buri and Mr. Noel Solis of the Abuaculture Department of the Southeast Asian Fisheries Development Center (SEAFDEC), for their assistance in the collection of the information.

Special thanks go to Mr. Panfilio LEGASPI, Jr., for preparing the illustrations, without his fine work this work would be far from useful.

\section{References}

Мотон, Н., 1980. Fishing gear for prawn and shrimp used in the Philippines today. Tech. Rep. Aquacult. Dept. SEAFDEC, (5) : 43 pp.

Мотон, H., 1981. Studies on the fisheries biology of the giant tiger prawn, Penaeus monodon in the Philippines. Tech. Rep. Aquacult. Dept. SEAFDEC, (7): 128 pp.

Мотон, H., 1983. Traditional devices for capturing crabs used in the Philippines today. Res. Crust., (12) : 1-9.

摘 要

既報に加えて, 現在フィリピンにおいて使用されているエビ漁具 6 種類, 即ち 1) cover pot, 2) triangular scoop net, 3) fyke net, 4) channel net, 5) motorized push net, 6) lobster cage を図示し記載した。そしてこれらは概して, 省エネルギータイプであること, またその伝 統器具・技術を保持する意味からも今後の継続使用が望をれることを付記した。 